\title{
Study of the drying kinetics of red chili (Capsicum annuum) in an indirect solar dryer tunnel type
}

\section{Estudio de la cinética de secado de chile rojo (Capsicum annuum) en un tipo túnel secador solar indirecto}

CASTILlO-TÉLlEZ, Margarita ${ }^{1} \uparrow$, CASTILlO-TÉLlEZ, Beatriz ${ }^{2 *}$, HERNÁNDEZ-CRUZ, Luz María $^{1}$ and MEJÍA-PÉREZ, Gerardo Alberto ${ }^{1}$

${ }^{I}$ Facultad de Ingeniería, Universidad Autónoma de Campeche, Campus $V$, predio $s / n$ por Av Humberto Lanz Cárdenas y Unidad Habitacional Ecológica ambiental, Col. Ex Hacienda Kalá, C.P. 24085, San Francisco de Campeche, Campeche, México

${ }^{2}$ Centro Universitario del Norte, Universidad de Guadalajara. Km. 191, México 45D No. 23, 46200 Jal.

$1^{\text {st }}$ Author: Margarita, Castillo-Téllez / ORC ID: 0000-0001-9639-1736, Researcher ID Thomson: S-2283-2018, CVU CONACYT ID: 210428

$1^{\text {st }}$ Co-author: Beatriz, Castillo-Téllez / ORC ID: 0000-0003-3747-6320, Researcher ID Thomson: S-2264-2018, CVU CONACYT ID: 210564

$2^{\text {nd }}$ Co-author: Luz María, Hernández-Cruz / ORC ID: 0000-0002-0469-5298, Researcher ID Thomson: H-3153-2018, CVU CONACYT ID: 662220

$3^{\text {rd }}$ Co-author: Gerardo Alberto, Mejía-Pérez / ORC ID: 0000-0003-1701-1171

DOI: $10.35429 /$ JTIP.2021.12.5.17.23

Received March 30, 2021; Accepted June 30, 2021

\begin{abstract}
The drying process is very intensive in energy consumption. Mexico is a major producer of food, especially of varieties of chilies, with quality culinary and medicinal properties. The $65 \%$ of the national market as a dry product, which gives a benefit. In the drying process, the convective technology was used, using a horizontal tunnel with direct solar heating air. The kinetics of the solar dryer with direct heating is possible, with an average drying time of 16 hours of solar irradiance. The tests were performed in Temixco, Morelos, Mexico, located at $18^{\circ} 51$ 'of $\mathrm{LN}$ and $99^{\circ} 14^{\prime}$ of LO, with average values of $850 \mathrm{~W} / \mathrm{m}^{2}$ irradiance maximum. The chamber temperatures were in a range between 31 and $45^{\circ} \mathrm{C}$. The air velocity range was set between 1.3 and $2.4 \mathrm{~m} / \mathrm{s}$. Final moisture contents of the dried chili were obtained in a range between $8 \%$ and $6 \%$ h.b. with an average drying velocity of 4.7 humidity degree/h. The solar direct drying is a technology that allows recovering and trying different agricultural surpluses and could promote the establishment of agroindustries.
\end{abstract}

Solar drying, Indirect solar dryer, Solar air collector

\begin{abstract}
Resumen
El proceso de secado es muy intensivo en el consumo de energía. México es un gran productor de alimentos, especialmente de variedades de chilis, con una gran calidad culinaria y propiedades medicinales. El $65 \%$ del mercado nacional es como producto seco, lo cual le da un valor agregado. En el proceso se utilizó un secador de túnel con calentamiento solar de aire directo. La cinética del secador solar con calentamiento directo es factible, con un tiempo de secado de 16 horas de irradiancia solar. Las pruebas se realizaron en Temixco, Morelos, México, localizado a $18^{\circ} 51^{\text {' }}$ de $\mathrm{LN}$ y $99^{\circ} 14^{\prime}$ 'de LO, con valores de irradiancia máximos promedio de $850 \mathrm{~W} / \mathrm{m}^{2}$. Las temperaturas en la cámara fueron en un intervalo entre $31{ }^{\circ} \mathrm{C}$ y $45{ }^{\circ} \mathrm{C}$. El dominio de velocidades de aire se estableció entre 1.3 y $2.4 \mathrm{~m} / \mathrm{s}$. Se obtuvieron humedades finales del chili seco en un intervalo entre $8 \%$ y $6 \%$ en base humedad, con velocidades promedio de secado de 4.7 grados de humedad/h. Esta tecnología permite recuperar y tratar diferentes excedentes agrícolas y podría promover la creación de agro-industrias.
\end{abstract}

Secado solar, Secador indirecto, Colector solar de aire

Citation: CASTILLO-TÉLLEZ, Margarita, CASTILLO-TÉLLEZ, Beatriz, HERNÁNDEZ-CRUZ, Luz María1 and MEJÍAPÉREZ, Gerardo Alberto. Study of the drying kinetics of red chili (Capsicum annuum) in an indirect solar dryer tunnel type. Journal of Technologies in Industrial Processes. 2021. 5-12: 17-23

\footnotetext{
* Author Correspondence (mcastill@uacam.mx)

$\dagger$ Researcher contributing as first author.
} 


\section{Introduction}

Among the significant contributions of Mexico to the world stands out the great diversity of domesticated plants such as chili, diversified throughout history by the native peoples to use them for medicinal, ornamental, stimulating drinks, or as a condiment. The chili (Capsicum spp.) belongs along with tomato, eggplant, tobacco, and potato, to the family of Solanaceae. The genus includes about 26 species, all native to the Americas. Its scientific name Capsicum comes from the Greek kapsakes or capsule. Its common name comes from the Nahuatl chili (CONABIO, 2020).

For more than 500 years, chili has been the food sustenance of Mexicans; Currently, it remains the primary ingredient of Mexican foods, being present in up to $90 \%$ of its dishes either directly (chopped or in rajas) or as a fundamental ingredient of sauces, marinades, moles and dressings. Chili in Mexico is also a symbol of identity, it is the flavor that unites the family, and it is the crop that prevails in their lands (INAH, 2020). Its fruits are consumed both fresh and dry to provide color, flavor and, aroma to countless dishes, which places it among the main spices.

Mexico is the world's number one exporter of chili peppers and peppers; being $29.71 \%$ of its total production what is destined to the international market. Currently, the main destination of these products is the U.S., chili imports for that country are $77.99 \%$ Mexican products; followed by Canada with 55.45 and Guatemala, whose chili imports are $52.25 \%$ Mexican (SIAP, 2019).

The average annual growth of chili production is $4.82 \%$; is forecast that for the $4.82 \%$; this forecast that for the period that began in 2016 and will end in 2030, the cumulative production growth will be $61.40 \%$; while for exports in millions of tons it is $139.66 \%$ (SAGARPA, 2019). The cultivation of the different varieties of chili adapts to different climates and soil types at altitudes ranging from sea level to $2500 \mathrm{~m}$. In the Yucatan Peninsula and Tabasco jalapeños, coastal and habaneros are planted. Consequently, its consumption is equally diverse: the fresh is usually used as a vegetable or condiment; the dry one is mainly destined to the food and pharmaceutical industry (Hernández and Muñoz, 2015).
Concerning dried chili, Zacatecas is the country's primary producer, contributing more than $50 \%$ of the national production, in an annual area ranging between 30 and 40 thousand hectares (Sagarpa, 2008). Indirectly, this production generates thousands of additional jobs in the more than 100 dehydrators, the food industry, the transport industry, and input suppliers operating in the State and the country.

The denomination of green chili is for natural or processed fruits and, when dehydrated, they pass to the group of dried ones, as is the case of the ancho, mulato, guajillo, costeño chilis, among many others. Dried chili peppers are allowed to ripen and dry, are already dry, are widely used in Mexican cuisine, and are characterized by a mild and less spicy flavor than fresh ones.

About marketing, the price of dried chili concerning green is sometimes up to $50 \%$ higher since it provides an added value to the product through the manufacture of sauces or powder properly packaging, which allows it to obtain better prices in the market and raise the life on the shelf.

The coastal chili is mainly marketed dry, sauce, chili, atole, roasted, powdered, and yellow mole; it is a thin variety, approximately 8 to $10 \mathrm{~cm}$ long. Currently, the coastal chili is competing with chilis produced in several states, on a large scale, and marketed throughout the country: the ancho chili, the guajillo, the puya, as well as others similar to the costeño chili: the tree and the serrano (Aguilar-Méndez, et al. 2018).

Chili is one of the most important crops in Mexico and the world; Mexico is the country with the most remarkable diversity of Capsicum annuum, where it is grown practically throughout the territory, with production systems and very diverse problems. Therefore, it is of the utmost importance to have new information on the cultivation of chili (Domínguez et al., 2015).

In this work, a study of the kinetics of the solar drying of the "costeño" chili produced in the State of Tabasco is carried out using a horizontal tunnel type dryer operated with direct solar air heaters. 


\section{Experimental study}

The experiments were carried out in the Drying Laboratory and in the Solar Platform of the Institute of Renewable Energies of the Universidad Nacional Autónoma de México, located in the City of Temixco, State of Morelos, Mexico, located at $18^{\circ} 51^{\prime}$ of L.N. and $99^{\circ} 14^{\prime}$ of L.O., at $1250 \mathrm{msnm}$.

\subsection{Indirect solar dryer tunnel type}

The direct drying system consists of a drying tunnel, a solar air heating system, a fan to induce air through the tunnel, and a voltage variation to obtain different air velocities within a domain established between 2 and $4 \mathrm{~m} / \mathrm{s}$, support to maintain good inclination of the collector, as well as air inlet and outlet ducts. Figure 1 shows a view of the horizontal drying tunnel with the air heater integrated.

\subsubsection{Drying chamber}

The drying chamber consists of a rectangular shape placed horizontally, with a cross-section of $0.30 \mathrm{~m}^{2}$. The structure is metallic, thermally insulated. They can be treated up to $4000 \mathrm{~m}^{3} \mathrm{~h}^{-1}$ to obtain a maximum velocity of $4 \mathrm{~ms}^{-1}$. The total length of the drying tunnel is $6 \mathrm{~m}$, with an active length of $5 \mathrm{~m}$. The tunnel has an external diffuser and an air filter at the entrance. At the exit, you have a fireplace with a height of $3.5 \mathrm{~m}$. The drying tunnel is divided into five sections, and in each section, there are three trays at different levels to contain the product to be dried.

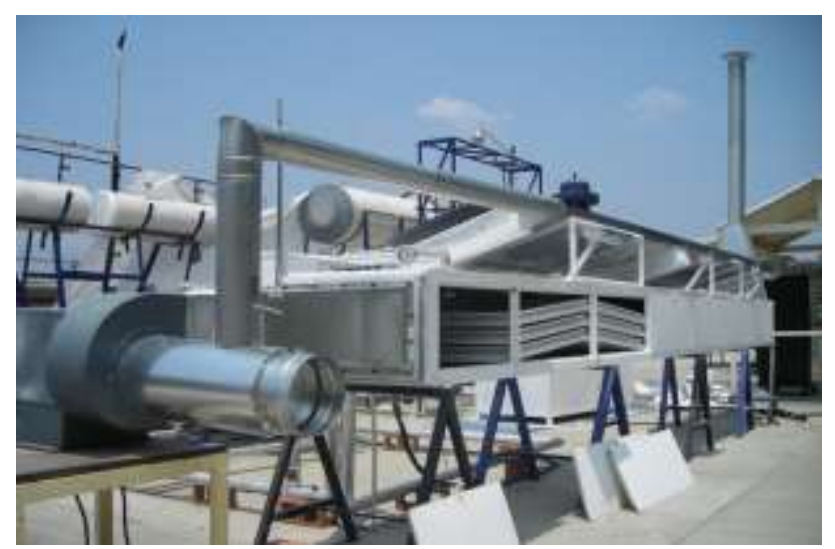

Figure 1 General view of the solar dryer with direct air heating

Source: Author Photo

\subsubsection{Solar air heating system}

The thermal energy needed for air heating is provided utilizing a direct solar heating system. The direct solar air heater consists of an absorber plate formed inside rectangular tubular sections covered with a matte black pigment of high temperature and absorptivity to solar radiation. Air flows inside through the channels of the structure.

The absorber surface with an area of 1.22 $\mathrm{m}^{2}$ has a typical transparent glass cover $2 \mathrm{~m}$ long by $66 \mathrm{~cm}$ wide and $3 \mathrm{~mm}$ thick. The lateral and posterior parts were thermally insulated using polyethylene foam with a thickness of $25 \mathrm{~mm}$, and thermal conductivity of $0.0236 \mathrm{~W} / \mathrm{mK}$. The collector is protected by an aluminum housing 2 $\mathrm{m}$ long by $67 \mathrm{~cm}$ wide and $9 \mathrm{~cm}$ high and is mounted on a pair of supports that allow it to have an inclination of $20^{\circ}$ on the horizontal facing south. Figure 2 shows a view of the solar air heater.

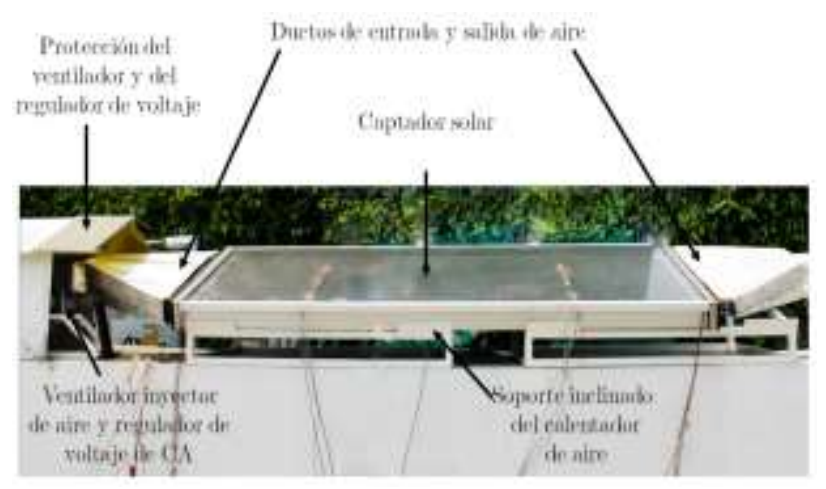

Figure 2 View of the solar air heater Source: Author's Photo

\subsubsection{Characterization of the solar air heater}

The solar air heater was subjected to different tests to determine its thermal efficiency applying the ASHRAE standard in solar air heaters; the reported results are based on the temperature of the inlet air of the solar collector, the ambient temperature, and incident radiation.

Graph 1 shows the temperature differences: average, maximum and minimum, between the output and entry of air to the solar collector for the four different speeds $2,3,5$, and $8 \mathrm{~m} / \mathrm{s}$ and the corresponding volumetric flows. As can be seen, the difference in temperatures decreases as both the speed and volumetric flow of air increase. 


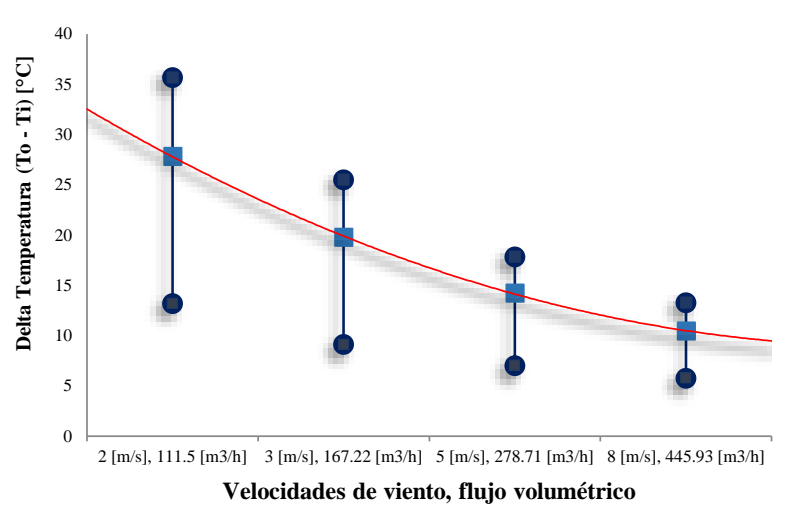

Figure 1 Variations in the temperature difference reached as a function of volumetric air velocities and flows

Graph 2 represents the evolution of the efficiency and average temperature of the collector as a function of volumetric flow. Generally speaking, efficiency increases with the increasing volumetric flow and decreases with increasing temperature. Therefore, it was possible to obtain the thermal efficiency of the solar air heater between 0.5 and 0.7 , which coincides with the values reported in the literature within the domain of the airflow analyzed.

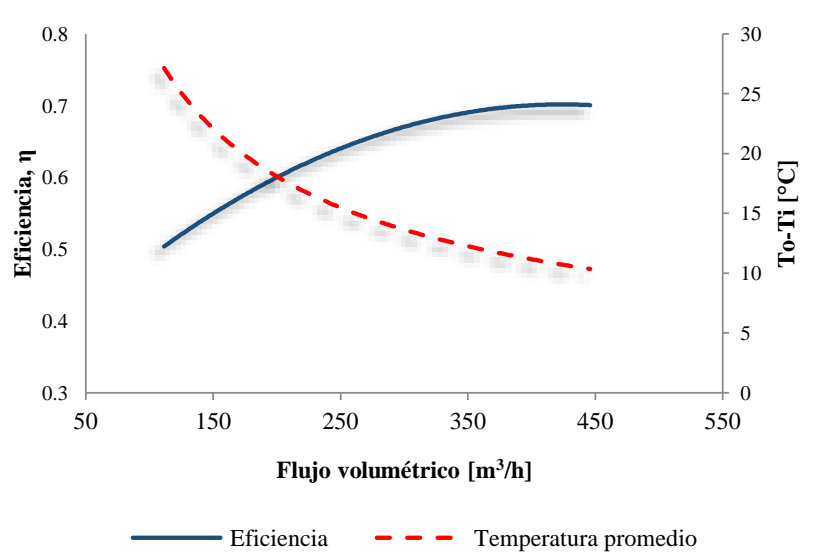

Figure 2 Evolution of efficiency and temperature differences obtained at different volumetric flow conditions

\section{2 Drying of chili}

\subsubsection{Weather conditions}

During the testing period, the climatic variables of temperature and relative humidity of the air were recorded and global solar radiation. Data on these variables were obtained from the weather station of the Institute of Renewable Energies of the National Autonomous University of Mexico.
Graph 3 shows that during the test period, the ambient temperature ranged in minimum values between 26.76 and $27.69^{\circ} \mathrm{C}$ and maximum values between 31.9 and $33.7^{\circ} \mathrm{C}$. Concerning relative humidity, low values were obtained. It varied between $29.2 \%$ and $18.06 \%$ for the first day, for the second day $32.65 \%$ and $21.6 \%$, finally for the third day, $25.49 \%$ and $22.6 \%$. The global solar irradiance values for the testing period are presented in Figure 4. The radiation varied between average maximum values between 990,954 , and $990 \mathrm{~W} / \mathrm{m}^{2}$, with 6 $\mathrm{h}$ of insolation for the first day, $7 \mathrm{~h}$ for the second, and only $3 \mathrm{~h}$ for the third $16 \mathrm{~h}$ effective solar operation for the drying process.

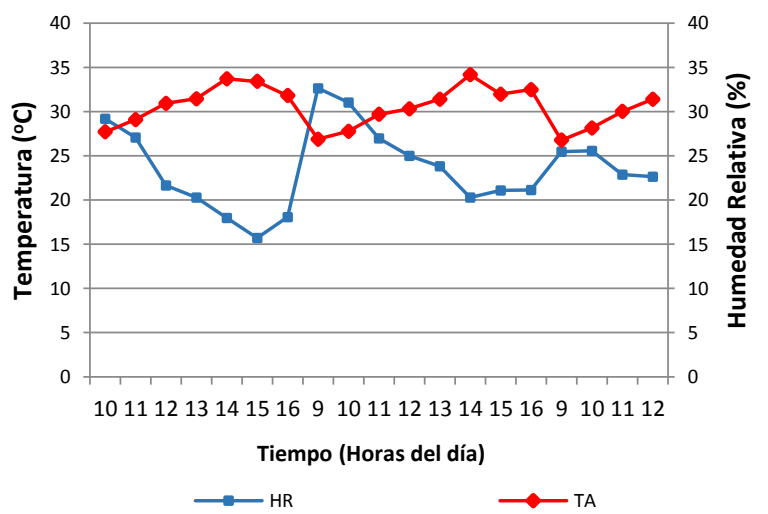

Figure 3 Evolutions of relative humidity and air temperature during test days

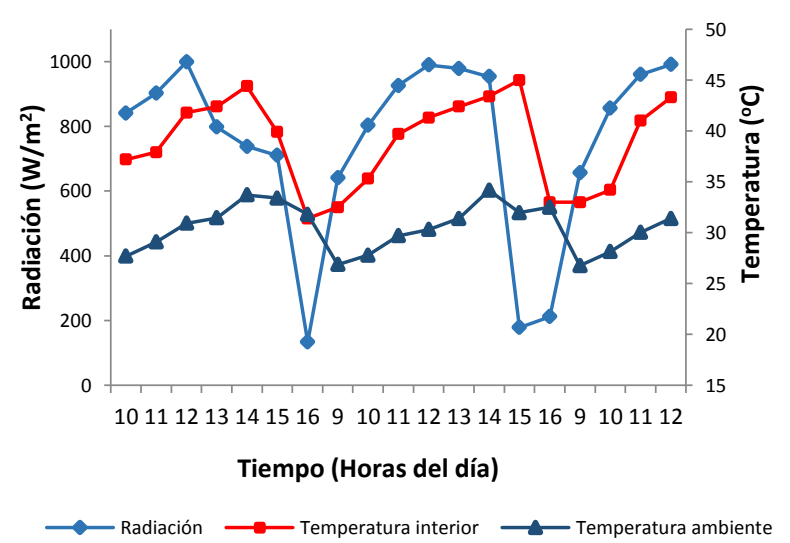

Figure 4 Evolutions of solar irradiance, ambient temperature and inside the drying chamber during the test days

\subsubsection{Materials and methods 2.2.2.1 Materials}

For the experimentation was used red chili "costeño", of the variety Capsicum annuum, grown in the Municipality of Emiliano Zapata, in the State of Tabasco, Mexico. Samples of green chili and different levels of maturation were used. 
In addition, the degrees of humidity was determined, as well as the corresponding densities. For the drying process, whole and complete chili peppers were selected, seeking the same size, average maturity, and unit weight variations between 10.7 and $9.2 \mathrm{~g}$.

\subsubsection{Determination of moisture content}

The humidity of the different samples was made using a humidity analyzer brand Ohaus model MB45 of halogen type, with an accuracy of $1 \mathrm{mg}$ $\pm 0.01 \%$ in a temperature domain of 50 to 200 ${ }^{\circ} \mathrm{C}$. The initial humidities of green chili varied between $80.65 \%$ and $88.83 \%$, while samples of mature chili peppers ranged between $75.38 \%$ and $83.1 \%$; the variations are attributed to differences in the degree of maturation; the variations are attributed to differences in the degree of maturation.

\subsubsection{Solar drying}

In the tunnel of the solar dryer, the first section was used with only two trays, one upper and one intermediate, and in each of them, 25 samples of "coastal chili" were distributed, of which only two were identified in each tray, placed at the ends of them. Each of the samples was identified for subsequent weight loss recording. Once the trays were put, a first determination of the weights of each of the selected samples was made. The weight recording was done every 15 minutes and then every hour until a constant final weight was reached, and Ohaus brand balance was used with an accuracy of $0.1 \mathrm{~g}$.

The indirect solar dryer was implemented utilizing a fan that operates with different voltages to supply the tunnel with variable speeds. In this study, two air velocity levels were established, one high (between 2.6 and $1.4 \mathrm{~m} / \mathrm{s}$ ) and one lower in a domain of 0.7 to 1.63 and $\mathrm{m} / \mathrm{s}$. Figure 3 shows the tunnel-type indirect solar dryer and the arrangement of fresh chili peppers in the drying chamber.

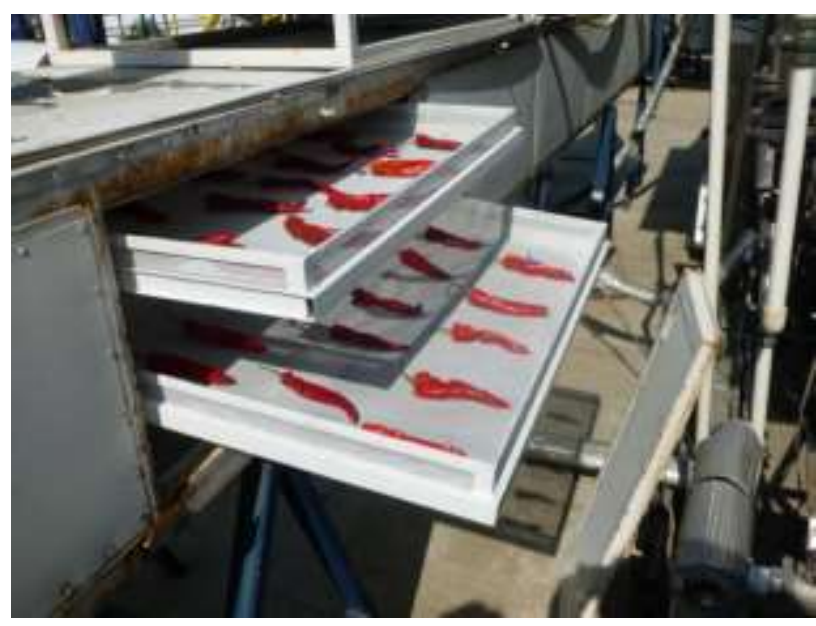

Figure 3 Disposal of fresh chili peppers in the drying chamber

Source: Author's Photo

\section{Experimental results}

In the tests with high velocity, during the first day, the air velocity varied between $2.4 \mathrm{~m} / \mathrm{s}$ and $1.4 \mathrm{~m} / \mathrm{s}$, the drying time was 6 hours, the second day, the air velocity varied between $2.4 \mathrm{~m} / \mathrm{s}$ and $1.8 \mathrm{~m} / \mathrm{s}$ with a duration of 7 hours and finally on the third day the air velocity variation was from $2.6 \mathrm{~m} / \mathrm{s}$ to $1.7 \mathrm{~m} / \mathrm{s}$, but for a time of only 3 hours because the final humidity conditions had already been reached.

Graph 5 shows the evolutions of the air temperature inside the drying chamber for the two different levels of velocity regimes. Regarding the high-velocity, the first-day temperature domain was obtained between 36.4 ${ }^{\circ} \mathrm{C}-46.4{ }^{\circ} \mathrm{C}$, the second day, 31.6 and $45.4^{\circ} \mathrm{C}$ and the third $34.3^{\circ} \mathrm{C}$ and $40.9^{\circ} \mathrm{C}$, with the average minimum temperature being 34.1 and the maximum temperature $44.23{ }^{\circ} \mathrm{C}$.

With the low-velocity, the first-day temperature was $37.2^{\circ} \mathrm{C}-44.4^{\circ} \mathrm{C}$, second day $31.4^{\circ} \mathrm{C}-45.0^{\circ} \mathrm{C}$, and the third $33^{\circ} \mathrm{C}-43.3^{\circ} \mathrm{C}$, with the average minimum temperature of $33.86^{\circ} \mathrm{C}$ and that of the maximum $44.23^{\circ} \mathrm{C}$.

\subsection{Drying kinetics}

Graphs 6-7 present the results of the moisture loss of the samples of the ripe coastal chili in the solar dryer operated with direct air heating. As can be seen in Graph 6, the evolutions of weight loss of samples 1 and 2 placed in tray two and the corresponding ones of samples 3 and 4 in tray 1 , above tray 2 , are presented. 


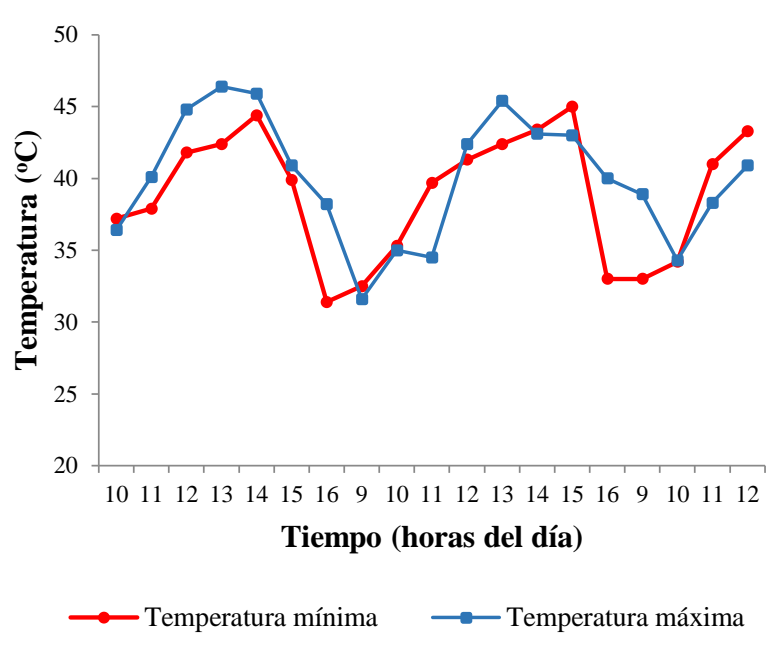

Figure 5 Evolution of the air temperature inside the drying chamber for the two different levels of velocity

In the maximum air velocity kinetics, the initial weights of the samples were for sample 1 : $8.2 \mathrm{~g}$, for 2: $9.2 \mathrm{~g}$, for 3:10.9 g, and 4: $9.9 \mathrm{~g}$. As can be seen, the drying kinetics are similar for the 4sample selected; in particular, the kinetics of 4 and 2 are practically the same. The fastest kinetics were sample 1, and the lowest was that of sample 3 with a higher mass. Final humidity varied in a domain of $5.26 \%$ to $6.27 \%$ in wet base, with an initial domain of $83 \%$ to $81.5 \%$, resulting in a total drying period of 16 hours effective solar irradiance with a difference in humidity between $78.7 \%$ and $76.24 \%$, which corresponds to an average of between 4.9 and 4.7 degrees of humidity/h of average drying speed, under the reported weather conditions.

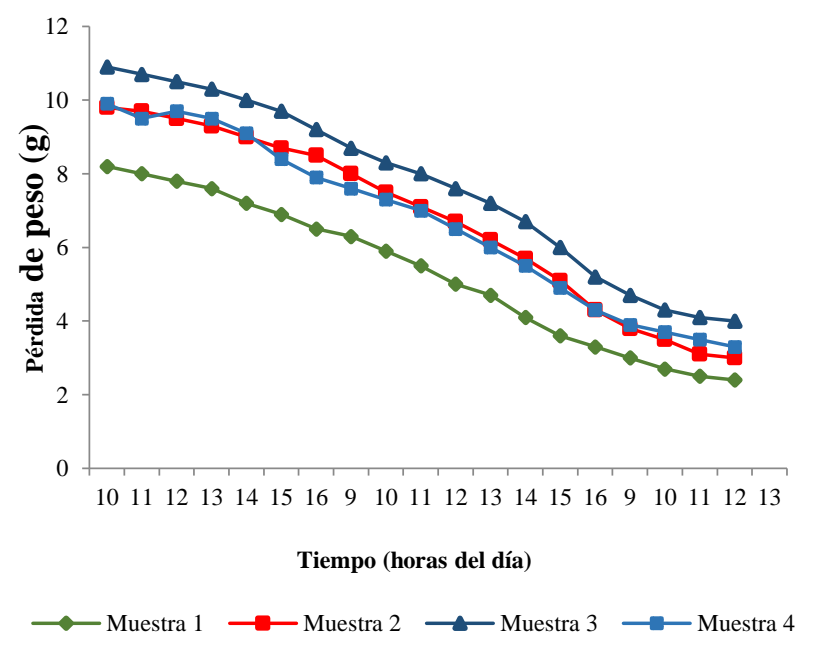

Figure 6 Solar kinetics of chili with high air velocity

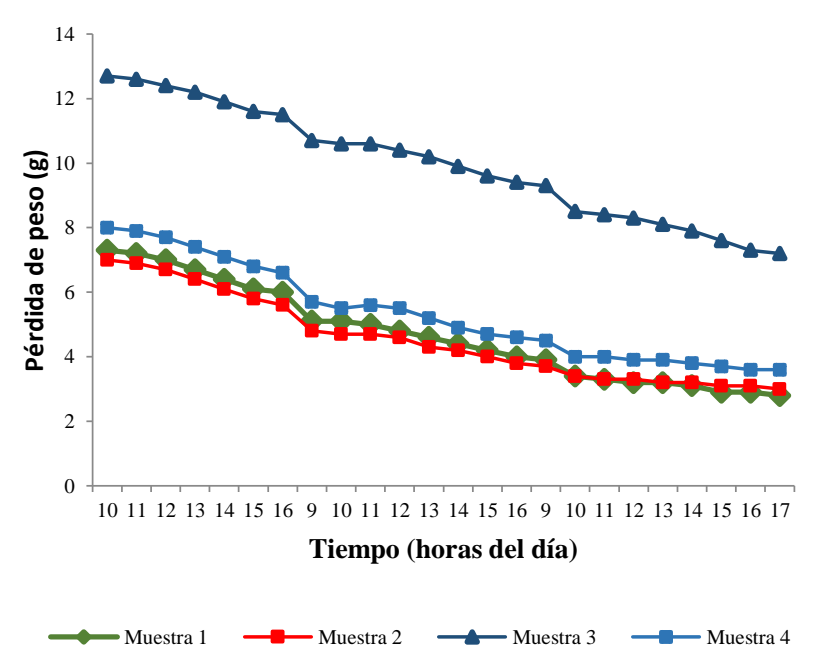

Figure 7 Solar kinetics of chili with low air velocity

Graph 7 presents the experimental results of the dehydration of coastal chili for low air velocity inside the chamber. In this case, the initial weights of the samples were for sample 1 : $7.3 \mathrm{~g}$, for 2: $7.0 \mathrm{~g}$, for $3: 12.7 \mathrm{~g}$, and for $4: 8.0 \mathrm{~g}$. The drying kinetics are practically the same and almost independent of the weight of the samples.

The initial humidity was practically the same as in the previous case; however, the final humidity was in a domain between 8.57 and $6.03 \%$ for the same drying time of 16 hours as in kinetics with high air velocity. The average humidity reduction was set at $75.57 \%$ resulting in an overall speed of $4.7^{\circ} / \mathrm{h}$, practically the same as with higher air velocities, so the air velocity between 2.6 and $1.4 \mathrm{~m} / \mathrm{s}$ has very little influence on the overall drying velocity for the domain of environmental conditions under which the experimental study was developed.

\section{Conclusions}

The drying kinetics of the "costeño" chili (Capsicum annuum) was determined in a direct solar dryer operating at two levels of air velocity. Mature chili was treated with initial humidities between 75.38 and $83.1 \%$ in wet base. The domain of the air velocity was established for both cases of regimes between $1.4 \mathrm{~m} / \mathrm{s}$ and 2.6 $\mathrm{m} / \mathrm{s}$, obtaining maximum temperature variations between 44.2 and $45^{\circ} \mathrm{C}$. for the same. In both cases, the drying time resulted in an average drying speed between 4.7 and $4.9^{\circ} \mathrm{C}$ humidity/h, resulting in a final humidity of the dry chili $8.57 \%$ and $6.03 \%$ for the low-velocity range $5.26 \%$ to $6.27 \%$ for the high. 
In addition, it was demonstrated the minor influence of the air velocity in the domain analyzed on the drying kinetics, using a tunnel dryer with direct air heating.

\section{References}

Aguilar Hernández, Raúl; Esparza Frausto, Gastón. Situación y perspectivas de la producción de chili seco en Zacatecas Revista de Geografía Agrícola, núm. 45, julio-diciembre, 2010. Universidad Autónoma Chapingo.

Araceli Aguilar-Meléndez, Marco Antonio Vásquez-Dávila, Esther Katz, María Reyna Hernández Colorado. Los chilis que le dan sabor al mundo. Universidad Vracruzana-Conabio, Primera edición. ISBN: 978-2-7099-2673-7.

Comisión Nacional para el Conocimiento y uso de la Biodiversidad. www. conabio.gob.mx/ usos/alimentacion/chili.html

Hernández Eva Aguirre y Muñoz Ocotero Verónica. El chili como alimento. revistaciencia.amc.edu.mx.

Instituto Nacional de Antropología, 2020. https://www.inah.gob.mx/reportajes/597-

Jorge A. Zegbe Domínguez, Ricardo D. Valdez Cepeda y Alfredo Lara Herrera. Cultivo de chili en México. Proy. Editorial Universidad Autónoma de Zacatecas (ISBN: 978-607-767869-4), 2012.

Sagarpa. Planeación agrícola nacional 20172030. Chilis y pimientos mexicanos, 2018.

Servicio de Información Agroalimentaria y Pesquera. Un panorama del cultivo del chili, 2019. https://www.gob.mx/siap. 